\title{
Oppgitt turnuslege
}

\author{
Er det mulig å komme seg i jobb igjen som lege etter å ha vært alvorlig psykisk syk?
}

Jeg har gjennomgått grundig sakkyndig psykiatrisk vurdering for å se om jeg kan komme tilbake til legeyrket. Psykiateren mente at jeg skal gradvis friskmeldes, bli ferdig med turnustjenesten og jobbe som lege. Med bakgrunn i denne vurderingen ga Statens autorisasjonskontor for helsepersonell beskjed om at jeg kan skaffe meg hospiteringsplass og jobbe som underordnet lege.

Jeg var veldig stolt over vurderingen fra psykiateren. Den ga meg tro og håp om at jeg skal klare å realisere meg selv. Jeg var glad for å få en psykiatrisk diagnose. Det ble påpekt at kommunikasjonsproblemer var grunnen til at turnustjenesten ikke ble godkjent. Disse problemene hadde sin bakgrunn i den psykiske sykdommen jeg hadde - og de er borte nå. Sykdommen er i remisjon under pågående behandling.

Nav prøvde å skaffe meg hospiterings- plass ved det lokale sykehuset, men det gikk ikke. Sykehuset sa pent nei til hospitering. Ettersom jeg var psykisk syk da jeg var der som turnuslege, ville det bli tungt for legene å ha meg der, fikk jeg vite. Jeg spurte da om Nav kunne hjelpe med å skaffe hospiteringsplass ved et annet sykehus, men de sier at det må jeg ordne selv. Hvis jeg ikke klarer å få meg hospiteringsplass på sykehus, bør jeg tenke på alternative jobber.

Da jeg søkte hospiteringsplass ved et annet sykehus, fikk jeg beskjed om at budsjettet ikke tillater sykehuset å bruke ressurser på å gi meg nødvendig veiledning - dermed kan man ikke tilby hospitering. Kan Legeforeningen hjelpe? Nei, ikke i sånne situasjoner. Legeforeningen kan ikke pålegge sykehus å gi hospiteringsplass til en i min situasjon.
Av og til tenker jeg at det kanskje ville vært bedre om psykiateren hadde sagt til meg at det ikke er mulig for meg å bli lege i det systemet vi har. Da kunne jeg ha gitt opp drømmene mine.

Jeg håper at mange legestudenter $\mathrm{og}$ leger leser dette. Jeg har erfart noe som mange kan ta lærdom av, mener jeg. Man skal kjempe for å bli frisk etter en alvorlig psykisk sykdom, men det er tungt å kjempe mot systemet også.

\section{Oppgitt turnuslege}

Forfatteren er anonym, men vedkommendes identitet er kjent for redaksjonen.

Mottatt 26.9. 2013 og godkjent 26.11. 2013. Redaktør Erlend Hem.

\section{Kommentar}

\section{Når legen blir alvorlig syk}

Den anonyme turnuslegens innlegg er tankevekkende. Det reiser to hovedspørsmål: hensynet til pasientene og hensynet til legen. Universitetene skal kvalitetssikre medisinstudentene før turnustjeneste. Det er nok mer systematikk i kvalitetssikringen av teoretiske og praktiske ferdigheter enn av personlig egnethet. Deretter skal de klinisk ansvarlige godkjenne turnustjenesten. Det er bedre oppfølging nå enn for noen år siden - og noen kandidater får ikke godkjent tjenesten.

Etter godkjent turnustjeneste har tilsynsmyndighetene ansvaret for oppfølging og kontroll, som oftest etter klager eller bekymringsmeldinger.

Det er i hovedsak de samme forhold som kan føre til at turnustjenesten ikke blir godkjent og til at en lege fratas lisensen eller gis advarsel - nemlig manglende kunnskaper og ferdigheter eller manglende egnethet som følge av atferd, personlighet eller liknende (f.eks. alvorlig sinnslidelse, psykisk eller fysisk svekkelse, langt fravær fra yrket, bruk av rusmidler eller atferd som anses å være uforenlig med yrkesutøvel- sen). Dette er regulert i retningslinjer for turnustjenesten fra Sosial- og helsedirektoratet (1) og i lov om helsepersonell, særlig i $\S \S 56-59$ (2).

Et annet viktig spørsmål er hensynet til legen. Legeyrket er krevende. Det er mange leger som sliter, noe som blant annet viser seg i høyere selvmordsrate enn $i$ andre yrker (3). Blant annet derfor er det etablert ordninger som «lege for lege». På Villa Sana ved Modum Bad har mange leger fătt råd og hjelp for yrkesrelaterte plager (4). Selv om de fleste leger har muligheter til å få hjelp, er det er også et spørsmål hvor langt hjelpetiltakene skal strekkes.

Hva vil det si å bli alvorlig syk i psykiatrisk sammenheng? Selv om misbruk av vanedannende stoffer kan fore til tap av lisens, kan det også være forenlig med medisinsk praksis hvis vedkommende ikke møter beruset på jobb og misbruket ikke har ført til alvorlig funksjonsnedsettelse. Når det gjelder psykotiske lidelser, er nok problemene større. God behandling og oppfølging er viktig. Affektive lidelser er trolig like vanlig blant leger som blant andre. Det er mange med bipolar lidelse som fungerer utmerket som lege i gode faser. En personlighetsforstyrrelse behøver ikke å være til hinder for å fungere som lege. Ved alvorlige tilstander kan imidlertid problemene bli store, særlig ved narsissistiske og antisosiale former med begrenset evne til innsikt.

Den aktuelle turnuslegen anfører at kommunikasjonsproblemer var hovedårsaken til at han ikke fikk godkjent turnustjenesten. Det er vanskelig å sette opp kriterier for hva som er bra nok kommunikasjon, men det er vanligvis alvorlig når slike problemer fører til tap av lisens. Hvis kommunikasjonsproblemer skal være årsaken til manglende godkjenning, bør det konkretiseres hvordan atferden har vært, slik at også andre kan forstå begrunnelsen.

Det er nødvendigvis en stor belastning for en lege ikke å få godkjent turnustjenesten eller å miste lisensen senere i yrkeskarrieren. Det er flere muligheter for faglig støtte, både under turnustjenesten og senere. Samtidig 
må vi huske at det viktigste er å sikre at pasientene møter kvalifiserte leger. Her har universiteter, avdelingsledere og tilsynsmyndigheter en krevende oppgave. Trolig er det flere uegnede som fortsatt får praktisere enn det er leger som har mistet lisensen uten grunn.

\section{Øivind Ekeberg}

oivind.ekeberg@ous-hf.no

Øivind Ekeberg (f. 1945) er spesialist i psykiatri og veileder i psykodynamisk psykoterapi. Han er overlege i psykiatri ved Akuttmedisinsk avdeling. Oslo universitetssykehus, Ullevål, og professor II i medisinske atferdsfag ved Institutt for medisinske basalfag, Universitetet i Oslo. Han arbeider klinisk og forskningsmessig særlig med selvmordsatferd, psykotraumatologi og psykiske reaksjoner ved somatisk sykdom.

Ingen oppgitte interessekonflikter.

\section{Litteratur}

1. Rundskriv IS-9/2005. Oslo: Sosial- og helsedirektoratet, 2005. www helsedirektoratet no/ publikasjoner/turnustjenesten-for-leger/Sider/ default.aspx (26.11.2013)

2. Lov om helsepersonell m.v. (helsepersonelloven). http://lovdata.no/dokument/NL/Lov/1999-07-02-64 (26.11.2013).

3. Hem E, Haldorsen T, Aasland OG et al. Suicide rates according to education with a particular focus on physicians in Norway 1960-2000. Psychol Med 2005; 35: 873-80.

4. Rø KE, Gude T, Tyssen R. Counselling for burnout in Norwegian doctors: one year cohort study. BMJ 2008; 337: a2004.

Mottatt 25.11. 2013 og godkjent 26.11. 2013

Redaktør: Erlend Hem 